\title{
Food preferences of golden jackals and sympatric red foxes in European temperate climate agricultural area (Hungary)
}

\author{
József Lanszki ${ }^{1 * *}$ and Miklós Heltai ${ }^{2}$ \\ ${ }^{1}$ Department of Nature Conservation, University of \\ Kaposvár, P.O. Box. 16, 7400 Kaposvár, Hungary, \\ e-mail: lanszki@ke.hu \\ ${ }^{2}$ Institute for Wildlife Conservation, St. István University, \\ Páter K. Str. 1., 2100 Gödölló, Hungary \\ *Corresponding author
}

\begin{abstract}
Differences in food preferences between two sympatric canids, the golden jackal (Canis aureus), which is currently spreading from south-east Europe and is a little-known species in Europe, and the red fox (Vulpes vulpes) were investigated. Data on diet composition and food availability were collected over a 13 -season period, in a temperate climate agricultural area of Hungary. We found that jackals and foxes preferred small mammals (Ivlev's electivity index, $\mathrm{E}_{\mathrm{i}}=0.38$ and 0.39 , respectively), and avoided towards wild boar $\left(\mathrm{E}_{\mathrm{i}}=\right.$ -0.43 and -0.56 , respectively) and cervids $\left(E_{\mathrm{i}}=-0.92\right.$ and -0.94 , respectively). Jackals preferred pheasant less than foxes $\left(E_{i}=0.06\right.$ and 0.51 , respectively). Within small mammals, both predators preferred the open field living species, with the forest living species being less favoured. The relationship between the available biomass of small mammals, as the primarily important food resource for both canids, and the proportion of consumed biomass of small mammals was not close. This was probably as a result of abundant food resources and high trophic flexibility of the golden jackal and red fox allowing these two closely related carnivores to coexist sympatrically in Central European areas without resource partitioning.
\end{abstract}

Keywords: Canis aureus; diet; electivity; food resource; Vulpes vulpes.

\section{Introduction}

The golden jackal (Canis aureus, Linnaeus 1758) is a widespread canid, occurring in northern and eastern Africa, Asia Minor, the Middle East, central and southern Asia, and south-eastern Europe (Krystufek et al. 1997, Macdonald and Sillero-Zubiri 2004). The jackal is listed as an "Extinct" native species in the Hungarian Red Data Book, because it disappeared from Hungary at the beginning of the 20th century as a result of changes to its natural habitats and the more general persecution of carnivores (Szabó et al. 2009). In the 1990s, the golden jackal started to recolonise the Carpathian basin (Central Europe) from the south. As a result, a study area was established on the north-western edge of the golden jackal range (Demeter and Spassov 1993, Krystufek et al. 1997, Szabó et al. 2009).

The red fox (Vulpes vulpes, Linnaeus 1758) is the most widespread member of the canids, occurring throughout Europe, Russia, North Africa and North America, as well as having been successfully introduced to Australia (Macdonald and Sillero-Zubiri 2004). It is also the most common carnivore in Hungary (Heltai et al. 2007a). Both the golden jackal and red fox inhabit a variety of ecoregions, where the distribution areas of these mesopredators partially overlap.

Feeding habits of the larger-sized $(7-15 \mathrm{~kg})$ golden jackal, which can hunt either as a solitary hunter or in pairs or groups (Lamprecht 1978, Macdonald 1979, 1983, Bekoff et al. 1984, Moehlman 1987, Admasu et al. 2004), differ from the smaller-sized (4-7 kg) and generally solitary red fox (Gittleman 1985, 1989). Previous studies revealed the golden jackal to be a 'searcher hunter' feeding upon a broad range of small-sized prey, such as rodents, hare, birds, reptiles and arthropods (van Lawick and van Lawick-Goodall 1970) but will also frequently consume plants (Balasubramanian and Bole 1993, Mukherjee et al. 2004), scavenge on domestic animal remains (Macdonald 1979, Poché et al. 1987, Amroun et al. 2006) or carcasses left by large predators (Kruuk 1972, Moehlman 1987). The jackal is a group-living canid, and not only a searcher but also a pursuer, successfully hunting medium- and larger-sized ungulates, such as Thomson gazelle (Gazella thomsonii) (Lamprecht 1978), calf (Yom-Tov et al. 1995) and in Europe, mouflon (Ovis musimon), roe deer (Capreolus capreolus) (Demeter and Spassov 1993) and wild boar (Sus scrofa) (Lanszki and Heltai 2002, Lanszki et al. 2009).

The red fox is a typical searcher hunter as well as a food generalist, also utilising a wide range of small-sized prey types or plants and carcasses in European habitats (Englund 1965, Goszczynski 1977, Macdonald 1977, Ferrari and Weber 1995, Jędrzejewska and Jędrzejewski 1998, Leckie et al. 1998). The diet composition and feeding habits of the red fox, e.g., the preference for small mammals (e.g., Microtus species) or hare is known from studies in Europe (Goszczynski 1977, Macdonald 1977, Leckie et al. 1998), whereas the feeding habits of the golden jackal are less well understood. In most studies no definite food preferences have been 


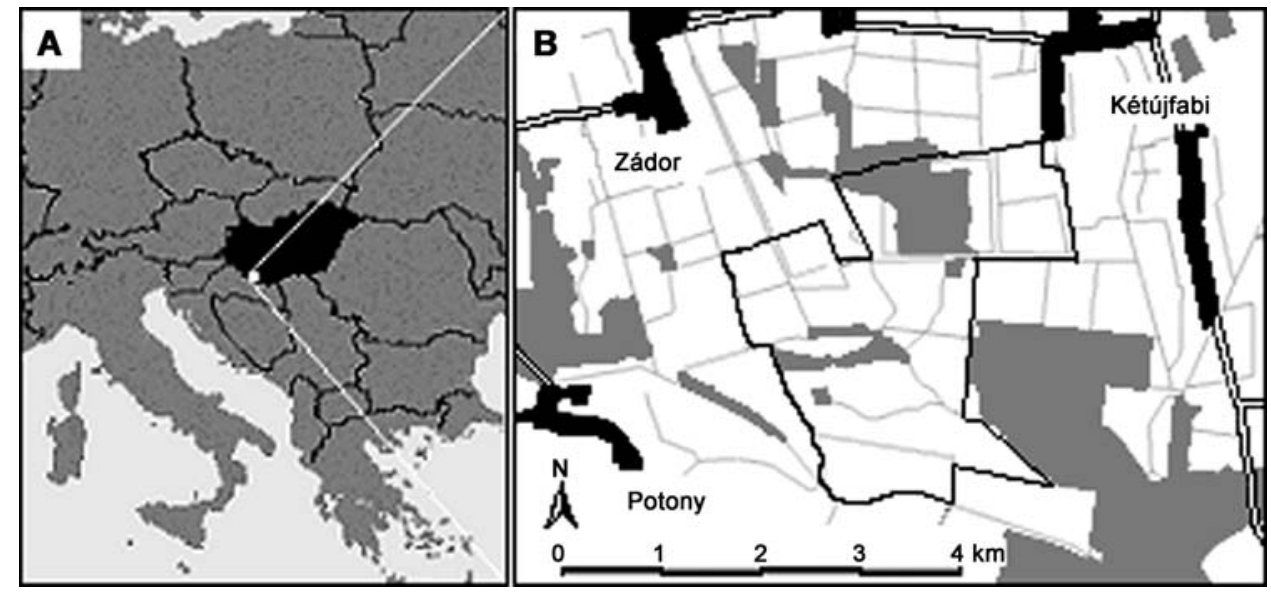

Figure 1 Geographic locality of the study area in Hungary (A), and habitat pattern of the study area (B). Border of the scat collection area (650 ha) is denoted with a black line, white surface denotes the open fields, dark grey denotes the forests, black denotes the villages, grey line denotes the canals (and shrubby areas), and double black line denotes the roads.

described for the golden jackal, which could be as a result of the perceived feeding opportunism of the species (Macdonald 1983, Gittleman 1985, 1989). If a predator consumes prey relatively more frequently than it exists in the population then it is considered preferred prey spp., whereas if it is taken less frequently it is avoided.

The ecological theory (Hardin 1960, Rosenzweig 1966) predicts that for two similar and closely related carnivores to coexist, they must reduce interspecific competition by partitioning resources (e.g., space, food). For example, predators with similar environmental requirements and/or similar body size segregate in their geographical range (e.g., grey wolf Canis lupus and golden jackal; Krystufek et al. 1997) or have a mosaic distribution throughout their area (e.g., the golden jackal, particularly on the edge of the species range; Demeter and Spassov 1993, Giannatos et al. 2005, Szabó et al. 2009). But, the golden jackal and the red fox are not separated in Hungary, even in areas where both canids are abundant (Heltai et al. 2007a,b).

In niche segregation, food separation can also have an important role (Schoener 1974). For example, in a temperate agricultural zone of North America, when the grey wolf (Switalski 2003) or the coyote (Canis latrans) (Crooks and Soulé 1999, Gosselink et al. 2003, Kamler et al. 2003) appeared, they had a significant negative effect on the abundance of smaller carnivores (such as domestic cat Felis catus, red fox, swift fox Vulpes velox). Consequently, smaller carnivores had a lower impact on, e.g., bird populations (Crooks and Soulé 1999).

Previously it was found that the dietary overlap between the golden jackal and the red fox could be high in agricultural areas (Lanszki and Heltai 2002, Lanszki et al. 2006), but the background of the interspecific (such as predatorpredator and predator-prey) interactions between these two canids are little known. To determine how and why the predators select their prey, knowledge of animal food availability is necessary. To increase our understanding of the return of the golden jackal to Central Europe, feeding studies, particularly those focusing on interspecific interactions and intraspecific (seasonal and food availability dependent) differences are important (Hayward and Kerley 2008).

The aim of this study was to use dietary and prey abundance data collected over 13 seasons in a temperate climate agricultural area, southwestern Hungary to determine which, if any animal food types golden jackals and red foxes prefer and which they avoid. Our data allowed direct comparison of preferences between the two sympatric canids at two levels; therefore, we also examined differences within the main animal food types and small mammals. Furthermore, we studied seasonal and year dependent differences.

\section{Materials and methods}

\section{Study area}

The study area is located in the Pannonian biogeographic region of southwestern Hungary (Ormánság region, 45 56' $\mathrm{N}, 17^{\circ} 41^{\prime} \mathrm{E}$; 103-123 m a.s.1., Figure 1). On the study area there are four main habitat types. During the study from September 2001 to November 2004, the area of abandoned fields (Erigeron spp.) decreased from $56.1 \%$ to $14.4 \%$, whereas the distribution of plough-lands (cereals and soy) increased from $10.9 \%$ to $48.7 \%$. The coverage of mixed oak-elm-ash forests (Quercus, Ulmus, Fraxinus spp.) and shrubby areas and banks (mainly Salix alba and Prunus spinosa) experienced only a small change $(22.9-29.5 \%$ and $10.2-7.4 \%$, respectively). The climate is continental. Duration of snow cover was 21, 48 and 16 days per year, and the mean snow depth was 70,84 and $18 \mathrm{~mm}$ per winter. During the study period, 2003 was an extreme year with a particularly cold and long winter, a hot summer and little rainfall. 


\section{Prey abundance}

Abundance of small mammals was determined by the capture-mark-recapture (CMR) method (Krebs 1989) with permission of the Directorship of the Danube-Drava National Park. From October 2001 to October 2004 seasonally, for four consecutive nights, 13 mammal trapping periods were undertaken. We distributed 199-299 glass-doored wooden live traps (size $180 \times 70 \times 70 \mathrm{~mm}$ ) throughout the four principal habitat types: a $10 \times 10$ grid $(n=100$ traps) on an abandoned field, $5 \times 20$ grid ( $\mathrm{n}=100$ traps) on plough-land (from spring to autumn), $7 \times 7$ grid $(n=49$ traps) in a forest, and 50 traps in a line along a shrubby bank approximately $10-\mathrm{m}$ wide. We situated the traps every $10 \mathrm{~m}$ and used walnuts, maize and ham as bait. We checked the sites twice daily at 6:00 h and 18:00 h. For identification of captured animals we used individual marking (Begon 1979) and recorded the weight of each animal. We determined the minimum number alive (MNA) value (Krebs 1966) and from this calculated the biomass of small mammals $\left(\mathrm{kg} / \mathrm{km}^{2}\right)$ using the summarised CMR data (from individual weights and MNA) for each season. Minimum abundance of ungulates and pheasant $\left(\mathrm{kg} / \mathrm{km}^{2}\right)$ were estimated on the basis of yearly summarised hunting bag data (official game management harvesting database). Individual weights of ungulates were measured with $0.1 \mathrm{~kg}$ accuracy, whereas weights of pheasants were assumed to be $1.0 \mathrm{~kg}$.

\section{Collection and analysis of scats}

For the preference calculation, the diet composition of the golden jackal and red fox were determined by the analysis of scats collected monthly between September 2001 and November 2004. A total of 626 jackal and 727 fox scats were collected over this period by travelling along a standard route $(12.8 \mathrm{~km}$ in $2001,21.3 \mathrm{~km}$ in 2002 and $22.7 \mathrm{~km}$ in 2003 and 2004) covering the 650-ha study area. Golden jackal and red fox scats were distinguished on the basis of odour, size and shape characteristics (Macdonald 1980). We used the standard wet procedure to analyse samples. To estimate the fresh mass of food ingested (Reynolds and Aebischer 1991), we weighed all dry food remains with the mass data and multiplied this by the appropriate conversion factor (summarised by Jędrzejewska and Jędrzejewski 1998).

Apodemus spp. comprise the yellow-necked mouse (A. flavicollis), common field mouse (A. sylvaticus) and striped field mouse (A. agrarius). Microtus spp. in the study area included the common vole (Microtus arvalis, 99\% of the Microtus species), field vole (Microtus agrestis) and European pine vole (Microtus subterraneus). The various species were grouped at the genus level, because it was not always possible to identify the individual species on the basis of hairs or teeth (März 1972, Teerink 1991, and our own reference collections) found in the scats. More details about the sampling methods and diet composition of jackals and red foxes are available in Lanszki et al. (2006). Necessary food composition data for the preference estimation are summarised in Appendix 1.

\section{Data analysis}

Ivlev's index $\left(\mathrm{E}_{\mathrm{i}}\right)$ of preference according to food items was applied as follows: $E_{i}=\left(r_{i}-n_{i}\right) /\left(r_{i}+n_{i}\right)$, where $r_{i}=$ percentage biomass of the given (ith) item in the diet and $n_{i}=$ percentage of biomass of the given (ith) item in the environment (Krebs 1989). Electivity varies from -1.0 to +1.0 , where -1.0 indicates avoidance, and +1.0 indicates a preferred prey. The preference indices from 13 seasons were compared with paired samples t-test between the two predators and with analysis of variance (ANOVA; Bonferroni test) among the food taxa.

The Spearman correlation $\left(r_{S}\right)$ test was used to examine the relationship between small mammal availability (biomass, $\mathrm{kg} / \mathrm{km}^{2}$ ) and proportion of consumed biomass (\% B) of small mammals. SPSS 10.0 for Windows (1999) statistical package was used for data processing.

\section{Results}

The biomass of small mammals in the community varied both seasonally and annually (Table 1 ). The trapping results

Table 1 Changes in availability and dominance of small mammals in southwestern Hungary.

\begin{tabular}{|c|c|c|c|c|c|c|c|c|c|c|c|c|c|}
\hline \multirow[t]{3}{*}{ Taxon } & \multicolumn{13}{|c|}{ Biomass $\left(\mathrm{kg} / \mathrm{km}^{2}\right)$} \\
\hline & \multirow{2}{*}{$\frac{2001}{\mathrm{Au}}$} & \multicolumn{4}{|l|}{2002} & \multicolumn{4}{|c|}{2003} & \multicolumn{4}{|l|}{2004} \\
\hline & & Wi & $\mathrm{Sp}$ & $\mathrm{Su}$ & $\mathrm{Au}$ & Wi & $\mathrm{Sp}$ & $\mathrm{Su}$ & $\mathrm{Au}$ & Wi & $\mathrm{Sp}$ & $\mathrm{Su}$ & $\mathrm{Au}$ \\
\hline Microtus spp. & 282.5 & 40.9 & 56.6 & 57.1 & 43.6 & 2.1 & 10.2 & 2.0 & 25.4 & 2.6 & 2.5 & 1.6 & 24.2 \\
\hline Myodes glareolus & 43.7 & & 1.5 & 19.9 & 21.7 & 2.3 & 6.3 & 14.8 & 16.1 & 10.8 & 12.6 & 32.6 & 25.0 \\
\hline Apodemus spp. & 119.3 & 25.2 & 19.8 & 71.8 & 137.4 & 2.7 & 16.4 & 58.9 & 163.7 & 27.0 & 28.2 & 45.5 & 129.9 \\
\hline Mus spicilegus & & & & & 2.4 & & & 0.1 & 0.3 & & 5.0 & 1.5 & 5.2 \\
\hline Micromys minutus & & & & & 0.5 & & & & 0.1 & & & & \\
\hline Sorex and Crocidura spp. & 23.1 & 0.7 & 1.2 & 6.8 & 16.2 & 0.1 & 1.3 & 2.0 & 17.6 & 0.1 & 0.1 & 0.1 & 1.0 \\
\hline Total & 468.7 & 66.8 & 79.1 & 155.7 & 221.8 & 7.2 & 34.3 & 77.8 & 223.2 & 40.5 & 48.3 & 81.3 & 185.3 \\
\hline
\end{tabular}

Biomass of small mammals was calculated from summarised capture data (from individual weights and MNA) in each season. Surveys were performed in winter (Wi), spring $(\mathrm{Sp})$, summer $(\mathrm{Su})$ and autumn (Au). Empty cells denote that the given taxon was not detected. 
4 J. Lanszki and M. Heltai: Food preferences of jackals and sympatric foxes

Table 2 Estimated abundance and preference of main animal food types of golden jackals and red foxes in southwestern Hungary.

\begin{tabular}{|c|c|c|c|c|c|c|c|c|c|c|c|c|}
\hline \multirow[t]{3}{*}{ Year } & \multirow{2}{*}{\multicolumn{4}{|c|}{$\frac{\text { Biomass }\left(\mathrm{kg} / \mathrm{km}^{2}\right)}{\text { Abundance of food types }}$}} & \multicolumn{8}{|c|}{ Ivlev's preference index $\left(\mathrm{E}_{\mathrm{i}}\right)$} \\
\hline & & & & & \multicolumn{4}{|c|}{ Jackal } & \multicolumn{4}{|l|}{ Fox } \\
\hline & SM & WB & $\mathrm{CE}$ & $\mathrm{PH}$ & SM & WB & $\mathrm{CE}$ & $\mathrm{PH}$ & $\mathrm{SM}$ & WB & $\mathrm{CE}$ & $\mathrm{PH}$ \\
\hline 2001 & $468.7^{\mathrm{a}}$ & 71.3 & 132.3 & 0.71 & 0.33 & -0.80 & -0.91 & 0.26 & 0.33 & -0.72 & -0.97 & 0.61 \\
\hline 2002 & 131.5 & 111.0 & 172.3 & 2.60 & 0.50 & -0.96 & -0.89 & -0.64 & 0.50 & -0.95 & -0.94 & 0.08 \\
\hline 2003 & 85.7 & 47.3 & 141.8 & 2.38 & 0.39 & 0.12 & -0.93 & 0.09 & 0.44 & -0.46 & -0.92 & 0.68 \\
\hline 2004 & 138.0 & 65.3 & 123.5 & 1.14 & 0.31 & -0.09 & -0.96 & 0.53 & 0.30 & -0.12 & -0.94 & 0.65 \\
\hline Mean $^{\mathrm{b}}$ & & & & & 0.38 & -0.43 & -0.92 & 0.06 & 0.39 & -0.56 & -0.94 & 0.51 \\
\hline
\end{tabular}

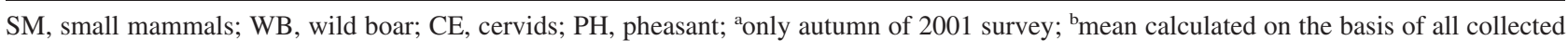
scat samples (13 seasons).

showed high density of rodents in autumn 2001, but in all other years the small mammal biomass in autumn was only half this level. An extremely low value $\left(7.2 \mathrm{~kg} / \mathrm{km}^{2}\right.$, Table 1) was measured during the long winter of 2003.

The composition of the small mammal community also changed during the study period. The Microtus spp. dominated in the first period of the study, whereas the Apodemus spp. dominated in the second period (Table 1). The bank vole (Myodes glareolus) was less frequent in the small mammal community. Steppe mouse (Mus spicilegus) and harvest mouse (Micromys minutus) occasionally occurred in the field, but at very low biomass values (up to $5.16 \mathrm{~kg} / \mathrm{km}^{2}$ and up to $0.47 \mathrm{~kg} / \mathrm{km}^{2}$, respectively). The biomass of ungulates and pheasant peaked in 2002 (Table 2). Biomass of the wild boar declined greatly, whereas biomass of cervids and pheasant decreased moderately during 2003.

Considering the main food items, both golden jackals and red foxes preferred small mammals (paired samples t-test, $\left.\mathrm{t}_{3}=0.53, \mathrm{p}=0.635\right)$ and, perhaps not surprisingly, avoided wild boar $\left(\mathrm{t}_{3}=0.88, \mathrm{p}=0.442\right)$, and cervids $\left(\mathrm{t}_{3}=0.90\right.$, $\mathrm{p}=0.434$ ) (Table 2). Jackals preferred pheasant less than foxes $\left(t_{3}=3.33, p<0.05\right.$, Table 2$)$. We found a high fluctuation in pheasant preferences between the years particularly in

Table 3 Preference of small mammal species by golden jackals and red foxes in southwestern Hungary.

\begin{tabular}{lcc}
\hline Prey species & \multicolumn{2}{c}{ Ivlev's preference index $\left(\mathrm{E}_{\mathrm{i}}\right)$} \\
\cline { 2 - 3 } & Jackal & Fox \\
\hline Microtus spp. & $0.58 \pm 0.082^{\mathrm{a}}$ & $0.55 \pm 0.085^{\mathrm{a}}$ \\
Myodes glareolus & $-0.53 \pm 0.074^{\mathrm{c}}$ & $-0.42 \pm 0.117^{\mathrm{b}}$ \\
Apodemus spp. & $-0.57 \pm 0.060^{\mathrm{c}}$ & $-0.45 \pm 0.074^{\mathrm{b}}$ \\
Mus spicilegus & $0.06 \pm 0.274^{\mathrm{b}}$ & $-0.23 \pm 0.323^{\mathrm{b}}$ \\
Micromys minutus & $0.90 \pm 0.085^{\mathrm{a}}$ & $0.96 \pm 0.026^{\mathrm{a}}$ \\
Sorex and Crocidura spp. & $-0.79 \pm 0.132^{\mathrm{c}}$ & $-0.75 \pm 0.140^{\mathrm{b}}$ \\
$\mathrm{p}$ & 0.001 & 0.001 \\
\hline
\end{tabular}

Mean \pm standard error (from 13 seasons). Differences among food taxa (within predator) marked with different letters $\left({ }^{\mathrm{a}, \mathrm{b}, \mathrm{c}}\right)$ are significant (ANOVA, Bonferroni test). the case of golden jackal (Table 2). The larger jackal had a higher preference for wild boar in 2003-2004 than in 2001-2002.

Considering only the primarily important small mammals of both predators, jackals preferred (ANOVA, $\mathrm{F}_{5}=31.26$, $\mathrm{p}<0.001$ ) open field living Microtus spp. and harvest mouse over steppe mouse (Table 3). They avoided the forest living bank vole and habitat generalist Apodemus spp. and shrews (which can live both in open fields and in forest or in shrubby habitats). Foxes preferred Microtus spp. and harvest mouse, and avoided steppe mouse, Apodemus spp., bank vole and shrews $\left(\mathrm{F}_{5}=19.78, \mathrm{p}<0.001\right.$, Table 3$)$. With the exception of Apodemus spp., no significant differences were found between predators in preference of each small mammal. Jackals in comparison with foxes less preferred Apodemus spp. (paired samples t-test, $\mathrm{t}_{12}=2.23, \mathrm{p}<0.05$ ).

Preference for Microtus spp. increased throughout the 4 years for both jackal $\left(\mathrm{E}_{\mathrm{i}}=0.21,0.33 \pm 0.11,0.68 \pm 0.12\right.$ and $0.81 \pm 0.08$, respectively, ANOVA, $\left.\mathrm{F}_{3}=4.45, \mathrm{p}<0.05\right)$ and fox $\left(E_{i}=0.19,0.30 \pm 0.11,0.63 \pm 0.15\right.$ and $0.80 \pm 0.07$, respectively, $\left.\mathrm{F}_{3}=4.19, \mathrm{p}<0.05\right)$. We did not find year-dependent differences $(0.794>p>0.05)$ in the other small mammal taxa. Both canids preferred Microtus spp. most in summer (both: $\mathrm{E}_{\mathrm{i}}=0.79$ ) and bank vole were avoided less in spring (jackal: $E_{i}=-0.30$, fox: $E_{i}=-0.21$ ), but the season-dependent differences within species was not significant (ANOVA, $\left.\mathrm{F}_{3}=0.59-0.76, \mathrm{p}>0.05\right)$, with the exception of steppe mouse which was preferred by the fox in winter and avoided in other seasons (ANOVA, $\mathrm{F}_{3}=22.06, \mathrm{p}<0.001$ ).

The proportion of consumed biomass of small mammals $(\% \mathrm{~B})$ showed no relationship with the available biomass of small mammals (jackal: $\mathrm{r}_{\mathrm{S}}=0.39, \mathrm{n}=13, \mathrm{p}=0.188$, fox: $\left.\mathrm{r}_{\mathrm{S}}=0.00, \mathrm{n}=13, \mathrm{p}=1.00\right)$.

\section{Discussion}

The results showed that the abundance of small mammals as primary prey of both golden jackal and red fox fluctuated between seasons and years. Abundance of supplementary foods, such as cervids, wild boar and pheasant also changed 
between years. Availability (biomass) of small mammals depended mainly on rainfall, but was not affected significantly by temperature. In northern latitudes, the availability of small mammals might have become a limiting factor for carnivores in relation to 3-4-year cycles of rodents, particularly Microtus species (Hansson and Henttonen 1985, Krebs 1996). The consequence of a long winter (Korslund and Steen 2006) is extreme weather conditions which could influence this cycle. Fluctuation of primary foods could affect the functional response of carnivores to different prey, for example, red foxes switched from voles (Microtus spp.) to less accessible mice (Apodemus spp.), hare and/or medium-sized birds (Angelstam et al. 1984, Lindström and Hörnfeldt 1994, Ferrari and Weber 1995, Leckie et al. 1998).

Despite this assumption, which might be from differences in body mass and potentially different hunting strategies (Gittleman 1985, 1989), feeding habits of the golden jackal showed high similarity to the red fox. Both species followed a typical searching strategy. Similar preferences for small mammals and similar avoidance of ungulates corroborate this. Avoidance of large-sized ungulates could be as a result of adult red deer and (fallow deer) active defence. Furthermore, wild boar are difficult prey for solitary jackals because of their tusks and aggression (Jędrzejewska and Jędrzejewski 1998), or when adult ungulates are scarce (authors' observations) or consume from carcasses. Roe deer (similarly to gazelles) would be small enough to fall prey to a pair of jackals as well as to family groups, but these animals are capable of rapid escape in mosaic habitats.

Negative preference values cover low consumption ratio, as in the case of cervids, including calves. Considering the main food taxa, a significant interspecific difference was only found in the consumption of pheasant. But the pheasant was consumed only in low numbers particularly by the jackal (Lanszki et al. 2006). Within the small mammal resource, both golden jackals and red foxes preferred the abundant, open field living Microtus spp. and avoided the habitat generalist Apodemus spp. and forest living bank vole. Avoidance of the bank vole, which is a slower moving species than the microtines, is unexpected, because carnivores generally prey upon slower-moving voles (and avoid faster-moving, very agile Apodemus spp.) from the rodent community (Jędrzejewska and Jędrzejewski 1998). These data corroborate that the golden jackal (and the red fox) characteristically prefer open habitats for hunting (Gittleman 1989); however, radiotelemetry (Loveridge and Macdonald 2003, Switalski 2003, Jaeger et al. 2007) could provide more information on how sympatric jackals and foxes separate in time and space in Central Europe.

There was no close relationship between primarily important small mammal availability and consumption ratio of small mammals, neither in the case of jackal nor of fox. Contrary to our results, in boreal and temperate zones (Goszczynski 1977, Angelstam et al. 1984, Jędrzejewska and Jędrzejewski 1998, Hanski et al. 2001) the diet of predators (red fox) was influenced by small mammal (in particular Microtus spp.) numbers. This could be because in Central
European agricultural environments small mammal (and animal food) resource is largely unlimited (Carbone and Gittleman 2002). With the exception of some periods (e.g., winter and spring of 2003), small mammals are usually accessible to predators. We found intraspecific differences in food preferences only when small mammal availability declined drastically. After a decline in the numbers of the main prey, jackals and foxes consumed more accessible animals or plants (Lanszki et al. 2006), confirming their generalist feeding strategy.

Our study area in Central Europe differs from areas in moderate (Gosselink et al. 2003, Switalski 2003) or boreal zones (Elmhagen et al. 2002, Helldin and Danielsson 2007) or southern latitudes (Stuart and Stuart 2003, Giannatos 2004, Scheinin et al. 2006) when larger predators entered a Carnivora community. Specifically, the diet compositions and consequently food preferences of the competitors rarely differed, and when it did it occurred only over a short period. By contrast, the presence of the golden jackal as a new predator would presumably have not significantly affected the feeding habits of the red fox, because in the Pannonian biogeographic region dominant and preferred foods of the red fox are small mammals (Lanszki et al. 2006). Our results differ from other studies because (1) food availability on northern and southern regions can be lower and/or less accessible than in our agricultural area and (2) larger-sized carnivores (wolf, lynx) are more food specialists than jackal and fox, and because of limited food resources can exclude the smaller carnivores. In our study area the density of both canids remained high. Mean density of jackals was 0.25 family groups $/ \mathrm{km}^{2}$ (authors' unpublished data) (determined by stimulated calling method, Giannatos et al. 2005) and density of foxes was 2.8 individuals $/ \mathrm{km}^{2}$ (Lanszki et al. 2006) (based on den density, inhabited den $\times 2$ ).

In conclusion, in this study both golden jackals and red foxes preferred small mammals. Of these, both predators favoured open field living species and showed less preference for forest living species. Preferences of their main food types did not differ substantially. The relationship between the small mammal availability and small mammal consumption ratio was not close. This indicates an unlimited and available food resource for both canids. Abundant food and flexibility of the omnivorous and opportunistic diet and feeding habits of golden jackal and red fox (Macdonald 1983, Gittleman 1985, 1989) probably allows these two closely related, medium-sized carnivores to coexist sympatrically in Central European agricultural areas.

\section{Acknowledgements}

We thank Jim Conroy, Amit Dolev, Krisztián Katona, Jenó Purger, Emese Szócs and two anonymous referees for their helpful advice and comments on the early draft of the manuscript. The study was supported by the Wildlife Fund of the Ministry of Agriculture and Rural Development. 


\section{Appendix}

Appendix 1 Number of scats analysed (n) and seasonal diet composition (percentage of biomass) changes of golden jackals and red foxes in southwestern Hungary.

\begin{tabular}{|c|c|c|c|c|c|c|c|c|c|c|c|c|c|c|c|}
\hline \multicolumn{2}{|c|}{ Year, season } & \multicolumn{7}{|c|}{ Jackal } & \multicolumn{7}{|l|}{ Fox } \\
\hline & & $\mathrm{n}$ & SM & WB & $\mathrm{CE}$ & $\mathrm{PH}$ & $\mathrm{OA}$ & PL & $\mathrm{n}$ & SM & WB & CE & $\mathrm{PH}$ & OA & PL \\
\hline 2001 & A & 100 & 95 & 3 & $<1$ & - & 1 & 1 & 104 & 88 & $<1$ & $<1$ & - & 6 & 6 \\
\hline \multirow[t]{4}{*}{2002} & W & 123 & 94 & $<1$ & 2 & - & 3 & 1 & 131 & 89 & $<1$ & 1 & 1 & 5 & 3 \\
\hline & $S$ & 44 & 91 & 2 & 1 & - & 4 & 2 & 53 & 89 & $<1$ & $<1$ & - & 9 & 2 \\
\hline & $\mathrm{Su}$ & 49 & 84 & 3 & 4 & 1 & 2 & 6 & 64 & 74 & 4 & 4 & 1 & 5 & 11 \\
\hline & A & 37 & 89 & $<1$ & 5 & 1 & $<1$ & 5 & 59 & 71 & A & $<1$ & $<1$ & $<1$ & 29 \\
\hline \multirow[t]{4}{*}{2003} & W & 40 & 80 & 13 & 2 & 2 & $<1$ & 2 & 46 & 81 & 6 & 1 & 1 & 1 & 10 \\
\hline & S & 36 & 53 & 15 & + & 0 & 29 & 2 & 33 & 64 & 6 & 3 & 15 & 9 & 3 \\
\hline & $\mathrm{Su}$ & 28 & 37 & 38 & $<1$ & - & $<1$ & 24 & 47 & 47 & 3 & 2 & - & 9 & 39 \\
\hline & A & 27 & 44 & - & 3 & 0 & 21 & 32 & 49 & 30 & 1 & $<1$ & $<1$ & $<1$ & 68 \\
\hline \multirow[t]{4}{*}{2004} & W & 58 & 80 & 7 & 1 & 3 & 4 & 4 & 50 & 54 & 4 & 2 & - & 6 & 33 \\
\hline & S & 21 & 49 & 41 & 2 & - & 6 & 2 & 27 & 59 & 31 & $<1$ & 3 & 3 & 3 \\
\hline & $\mathrm{Su}$ & 27 & 93 & - & + & + & 5 & 2 & 29 & 55 & - & 1 & 3 & 3 & 38 \\
\hline & $\mathrm{A}$ & 36 & 97 & & - & + & 2 & 1 & 35 & 72 & - & $<1$ & - & 1 & 28 \\
\hline
\end{tabular}

Seasons: A, autumn; W, winter; S, spring; Su, summer; food types: SM, small mammals; WB, wild boar; CE, cervids; PH, pheasant; OA, other animal foods; PL, plants; $<1$, between 0.05 and $0.5 \%,+$, biomass under $0.05 \%$; -, the given taxon was not detected (calculated from Lanszki et al. 2006).

\section{References}

Admasu, E., S.J. Thirgood, A. Bekele and M.K. Laurenson. 2004. Spatial ecology of golden jackal in farmland in the Ethiopian Highlands. Afr. J. Ecol. 42: 144-152.

Amroun, M., P. Giraudoux and P. Delattre. 2006. A comparative study of the diets of two sympatric carnivores - the golden jackal (Canis aureus) and the common genet (Genetta genetta) in Kabylia, Algeria. Mammalia 70: 247-254.

Angelstam, P., E. Lindström and P. Widén. 1984. Role of predation in short-term population fluctuations of some birds and mammals in Fennoscandia. Oecologia 62: 200-208.

Balasubramanian, P. and P.V. Bole. 1993. Seed dispersal by mammals at Point Calimere Wildlife Sanctuary, Tamil Nadu. J. Bombay Nat. Hist. Soc. 90: 33-44.

Begon, N. 1979. Investigating animal abundance: capture-recapture for biologists. Edward Arnold, London. pp. 97.

Bekoff, M., T. Daniels and J.L. Gittleman. 1984. Life history patterns and the comparative social ecology of carnivores. Annu. Rev. Ecol. Syst. 15: 191-232.

Carbone, C. and J.L. Gittleman. 2002. A common rule for the scaling of carnivore density. Science 295: 2273-2276.

Crooks, K.R. and M.E. Soulé. 1999. Mesopredator release and avifaunal extinctions in a fragmented system. Nature 400: 563-566.

Demeter, A. and N. Spassov. 1993. Canis aureus Linnaeus, 1758. In: (J. Niethammer and F. Krapp, eds.) Handbuch der Säugetiere Europas. Aula-Verlag, Wiesbaden. pp. 107-138.

Elmhagen, B., M. Tannerfeldt and A. Angerbjörn. 2002. Food-niche overlap between arctic and red foxes. Can. J. Zool. 80: 12741285.

Englund, J. 1965. Studies on food ecology of the red fox (Vulpes vulpes) in Sweden. Viltrevy 3: 371-442.

Ferrari, N. and J.M. Weber. 1995. Influence of the abundance of food resources on the feeding habits of the red fox, Vulpes vulpes, in western Switzerland. J. Zool. 236: 117-129.

Giannatos, G. 2004. Population status and conservation action plan for the golden jackal (Canis aureus) in Greece. WWF Greece, Athens. pp. 47. ((author: please provide more details: name and city of Publisher, names of editors, conference details))

Giannatos, G., Y. Marinos, P. Maragou and G. Catsadorakis. 2005. The status of the golden jackal (Canis aureus L.) in Greece. Belg. J. Zool. 135: 145-149.

Gittleman, J.L. 1985. Carnivore body size: ecological and taxonomic correlates. Oecologia 67: 540-554.

Gittleman, J.L. 1989. Carnivore group living: comparative trends. In: (J.L. Gittleman, ed.) Carnivore behavior, ecology, and evolution. Cornell University Press, New York. pp. 183-207.

Gosselink, T.E., T.R. Van Deelen, R.E. Warner and M.G. Joselyn. 2003. Temporal habitat partitioning and spatial use of coyotes and red foxes in east-central Illinois. J. Wildl. Manage. 67: 90103.

Goszczynski, J. 1977. Connections between predatory birds and mammals and their prey. Acta Theriol. 22: 399-430.

Hanski, I., H. Henttonen, E. Korpimäki, L. Oksanen and P. Turchin. 2001. Small rodent dynamics and predation. Ecology 82: 15051520.

Hansson, L. and H. Henttonen. 1985. Gradients in density variations of small rodents: the importance of latitude and snow cover. Oecologia 67: 394-402.

Hardin, G. 1960. The competitive exclusion principle. Science 131: 1292-1297.

Hayward, M.H. and G.I.H. Kerley. 2008. Prey preferences and dietary overlap amongst Africa's large predators. S. Afr. J. Wildl. Res. 38: 93-108.

Helldin, J.-O. and A.V. Danielsson. 2007. Changes in red fox Vulpes vulpes diet due to colonisation by lynx Lynx lynx. Wildl. Biol. 13: $475-480$. 
Heltai, M., J. Lanszki and L. Szemethy. 2007a. Vörös róka - Red fox. In: (Z. Bihari, G. Csorba and M. Heltai, eds.) Magyarország emlóseinek atlasza [The atlas of Hungarian mammals]. Kossuth Kiadó, Budapest. pp. 210-214.

Heltai, M., J. Lanszki, E. Szúcs and L. Szabó. 2007b. Aranysakál - Golden jackal. In: (Z. Bihari, G. Csorba and M. Heltai, eds.) Magyarország emlóseinek atlasza [The atlas of Hungarian mammals]. Kossuth Kiadó, Budapest. pp. 215-217.

Jaeger, M.M., E. Haque, P. Sultana and R.L. Bruggers. 2007. Daytime cover, diet and space-use of golden jackals (Canis aureus) in agro-ecosystems of Bangladesh. Mammalia 71: 1-10.

Jędrzejewska, B. and W. Jędrzejewski. 1998. Predation in vertebrate communities. The Bialowieza Primeval Forest as a case study. Springer-Verlag, Berlin. pp. 450.

Kamler, J.F., W.B. Ballard, R.L. Gilliland, P.R. Lemons and K. Mote. 2003. Impacts of coyotes on swift foxes in northwestern Texas. J. Wildl. Manage. 67: 317-323.

Korslund, L. and H. Steen. 2006. Small rodent winter survival: snow conditions limit access to food resources. J. Anim. Ecol. 75: 156-166.

Krebs, C.J. 1966. Demographic changes in fluctuating populations of Microtus californicus. Ecol. Monogr. 36: 239-273.

Krebs, C.J. 1989. Ecological methodology. Harper Collins, New York. pp. 654.

Krebs, C.J. 1996. Population cycles revisited. J. Mammal. 77: 8-24.

Kruuk, H. 1972. The spotted hyena. University of Chicago Press, Chicago, IL. pp. 335.

Krystufek, B., D. Murariu and C. Kurtonur. 1997. Present distribution of the golden jackal Canis aureus in the Balkans and adjacent regions. Mamm. Rev. 24: 109-114.

Lamprecht, J. 1978. On diet, foraging behaviour and interspecific food competition of jackals in the Serengeti National Park, East Africa. Z. Säugetierk. 43: 210-223.

Lanszki, J. and M. Heltai. 2002. Feeding habits of golden jackal and red fox in south-western Hungary during winter and spring. Mamm. Biol. 67: 128-136.

Lanszki, J., M. Heltai and L. Szabó. 2006. Feeding habits and trophic niche overlap between sympatric golden jackal (Canis aureus) and red fox (Vulpes vulpes) in the Pannonian ecoregion (Hungary). Can. J. Zool. 84: 1647-1656.

Lanszki, J., G. Giannatos, M. Heltai and A. Legakis. 2009. Diet composition of golden jackals during cub-rearing season in Mediterranean marshland in Greece. Mamm. Biol. 74: 72-75.

Leckie, F.M., S.J. Thirgood, R. May and S.M. Redpath. 1998. Variation in the diet of red foxes on Scottish moorland in relation to prey abundance. Ecography 21: 599-604.

Lindström, E.R. and B. Hörnfeldt. 1994. Vole cycles, snow depth and fox predation. Oikos 70: 156-160.

Loveridge, A.J. and D.W. Macdonald. 2003. Niche separation in sympatric jackals (Canis mesomelas and Canis adustus). J. Zool. 259: $143-153$.
Macdonald, D.W. 1977. On food preference in the red fox. Mamm. Rev. 7: 7-23.

Macdonald, D.W. 1979. The flexible social system of the golden jackal, Canis aureus. Behav. Ecol. Sociobiol. 5: 17-38.

Macdonald, D.W. 1980. Patterns of scent marking with urine and faeces amongst carnivore communities. Symp. Zool. Soc. Lond. 45: 107-139.

Macdonald, D.W. 1983. The ecology of carnivore social behaviour. Nature 301: 379-383.

Macdonald, D.W. and C. Sillero-Zubiri. 2004. Biology and conservation of wild canids. Oxford University Press, Oxford. pp. 450.

März, R. 1972. Gewöll- und Rupfungskunde. Akademie Verlag, Berlin. pp. 398.

Moehlman, P.D. 1987. Social organization in jackals. Am. Sci. 75: 366-375. ((please confirm that year is correct, it was 1983 in original paper))

Mukherjee, S., S.P. Goyal, A.J.T. Johnsingh and M.R.P. Pitman. 2004. The importance of rodents in the diet of jungle cat (Felis chaus), caracal (Caracal caracal) and golden jackal (Canis aureus) in Sariska Tiger Reserve, Rajasthan, India. J. Zool. 262: 405-411.

Poché, R.M., S.J. Evans, P. Sultana, M.E. Hague, R. Sterner and M.A. Siddique. 1987. Notes on the golden jackal (Canis aureus) in Bangladesh. Mammalia 51: 259-270.

Reynolds, J.C. and N.J. Aebischer. 1991. Comparison and quantification of carnivore diet by faecal analysis: a critique, with recommendations, based on a study of the Fox Vulpes vulpes. Mamm. Rev. 21: 97-122.

Rosenzweig, M.L. 1966. Community structure in sympatric Carnivora. J. Mammal. 47: 606-612.

Scheinin, S., Y. Yom-Tov, U. Motro and E. Geffen. 2006. Behavioural responses of red foxes to an increase in the presence of golden jackals: a field experiment. Anim. Behav. 71: 577-584.

Schoener, T.W. 1974. Resource partitioning in ecological communities. Science 185: 27-39.

SPSS For windows 1999. Version 10.0. Copyright SPSS Inc., Chicago, IL, USA.

Stuart, C.T. and T.D. Stuart. 2003. Notes on the diet of red fox (Vulpes vulpes) and Blanford's fox (Vulpes cana) in the montane area of the United Arab Emirates. Canid News 6: 4.

Switalski, T.A. 2003. Coyote foraging ecology and vigilance in response to gray wolf reintroduction in Yellowstone National Park. Can. J. Zool. 81: 985-993.

Szabó, L., M. Heltai, E. Szúcs, J. Lanszki and R. Lehoczki. 2009. Expansion range of the golden jackal in Hungary between 1997 and 2006. Mammalia 73: 307-311.

Teerink, B.J. 1991. Hair of West-European mammals. Cambridge University Press, Cambridge. pp. 224.

van Lawick, H. and J. van Lawick-Goodall. 1970. The innocent killers. Collins, London. pp. 222.

Yom-Tov, Y., S. Ashkenazi and O. Viner. 1995. Cattle predation by the golden jackal Canis aureus in the Golan Heights, Israel. Biol. Conserv. 7: 19-22. 